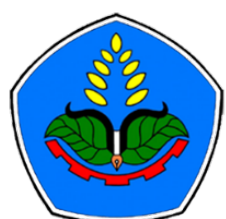

AGROPROSS

National Conference

Proceedings of Agriculture
Proceedings:

Peningkatan Produktivitas Pertanian Era Society 5.0 Pasca Pandemi

Tempat : Politeknik Negeri Jember

Tanggal : 22 Juli 2021

Publisher :

Agropross, National Conference Proceedings of Agriculture

ISBN : 978-623-94036-6-9

DOI : 10.25047 /agropross.2021.220

\title{
Kajian Konsentrasi Media dan Hormon untuk Konservasi Apel In Vitro
}

\author{
Author(s): Hidayatul Arisah ${ }^{(1)^{*}}$, Baiq Dina Mariana ${ }^{(1)}$, Marry Selvawajayanti ${ }^{(1)}$ \\ (1) Balai Penelitian Tanaman Jeruk dan Buah Subtropika Badan Litbang Pertanian Kementerian Pertanian \\ * Corresponding author: hidayatularisah@gmail.com
}

\begin{abstract}
Conservation of perennial plants such as apple is generally carried out in the field. However, due to the several obstacles triggered by climate change and pest and disease attack, a more efficient conservation system is needed, for example in vitro. In vitro conservation is an alternative for preserving clonal propagated plants such as apples. The study was aimed to know the effect of media strength and growth hormone concentration on in vitro conservation of apple. The research wasconducted at the Integrated Laboratory of ICSFRI from August to December 2018. The media tested were full (FS) and half strength (HS) of MS Media with the addition of BA. The accessions tested were K60, K66, K01, K84 and apple rootstock. The results showed that full strength MS media was better at maintaining explants alive than half-strength during the four months of conservation without subculture. The combination of MS FS and BA 0.1 mg L-1 media gave the best results for apple conservation for accessions K01 and K66.
\end{abstract}

Keywords:

apple;

in vitro

conservation;

MS media

\section{Kata Kunci: ABSTRAK}

apel;

konservasi in

Konservasi tanaman tahunan seperti apel umumnya dilakukan di lapang. Namun, karena

vitro; beberapa kendala yang dipicu oleh perubahan iklim dan serangan hama dan penyakit, diperlukan sistem konservasi yang lebih efisien, misalnya secara in vitro. Konservasi in vitro adalah alternatif untuk melestarikan tanaman yang diperbanyak secara klonal

media MS seperti apel. Penelitian ditujukan untuk melihat pengaruh perbedaan konsentrasi media dan ZPT untuk konservasi apel secara in vitro. Penelitian ini dilakukan di Laboratorium Terpadu Baltjestro dari Agustus hingga Desember 2018. Media yang diuji adalah Media MS dengankonsentrasi garam penuh (FS) dan setengah (HS) dengan penambahan BA. Aksesi yang diuji adalah K60, K66, K01, K84 dan batang bawah apel. Hasil penelitian menunjukkan bahwa media MS FS lebih baik dalam mempertahankan eksplan hidup daripada HS selama empat bulan konservasi tanpa subkultur. Kombinasi MS FS dan BA 0.1 mg L-1 memberikan hasil terbaik untuk konservasi apel untuk aksesi K01 dan K66. 


\section{PENDAHULUAN}

Apel adalah salah satu buah subtropika yang banyak diimpor untuk memenuhi permintaan masyarakat. Buah produksi dalam negeri hanya untuk tiga varietas yang adaptif di Indonesia, yaitu Manalagi, Rome Beauty dan Anna dengan daerah produksi terbatas di Jawa Timur. Selain tiga varietas tersebut tidak diketahui adanya varietas lain yang ditanam dalam skala produksi. Hal ini Karen adaya adaptasi apel yang rendah dan membutuhkan perawatan yang intensif untuk berproduksi di iklim tropis Indonesia.

Beberapa koleksi apel selain Manalagi, Rome Beauty dan Anna memiliki potensi untuk dikembangkan sebagai varietas baru. Namun pemeliharaan dan konservasi koleksi tersebut di lapang menunjukkan permasalahan yang rumit yang dipicu oleh perubahan iklim dan serangan hama penyakit yang pada akhirnya menyebabkan gangguan pertumbuhan. Oleh karena itu diperlukan metode konservasi lain yang lebih efisien dan berkelanjutan.

Selain konservasi in situ, konservasi ex situ meliputi kultur in vitro dan bank benih merupakan langkah yang dapat ditempuh dalam upaya pelestarian SDG (Kḷvina and Klavina, 2018). Pada umumnya tanaman buah tahunan berkayu seperti apel dipelihara di lapang. Namun sejalan dengan tantangan yang dihadapi di lapang untuk kegiatan konservasi, maka diperlukan alternative system penyimpanan dan pelestarian yang lebih sesuai. Kultur jaringan dapat digunakan untuk melestarikan tanaman dengan target konservasi berupa materi klonal (Oseni et $a l ., 2018)$ untuk konservasi tanaman yang diperbanyak secara vegetatif(Arbeloa et al., 2017). Tujuannya adalah untuk menghindari kehilangan tanaman baik karena bencana alam, seperti banjir, kekeringan serta serangan hama dan penyakit (Sedlak, Zidova, \& Paprstein, 2019).

Konservasi SDG secara in vitro dilakukan melalui prosedur kultur in vitro yang didesain untuk mereduksi laju pertumbuhan dari yang awalnya cepat menjadi lambat (slow growth). Slow growth (SG)dalam kultur in vitro diperoleh melalui pengurangan suhu, modifikasi media kultur dengan penambahan bahan osmotik dan penghambat pertumbuhan (Dewi et al., 2015) atau dengan menghilangkan pemacu pertumbuhan dengan tujuan untuk mengurangi metabolisme pada tingkat selular sehingga dapat memperpanjang periode waktu antar subkultur (review oleh da Silva dan Scherwinski-Pereira, 2011). Secara umum, periode konservasi dalam suhu dingin berkisar antara beberapa bulan hingga satu tahun. Hal ini dipengaruhi oleh ada tidaknya cahaya, umur, ukuran, status fisiologimateri kultur, dan optimasi untuk setiap spesies sangat diperlukan (Benelli et al., 2012).

Penambahan bahan osmotik dan pengurangan garam dan hormone dalam media menjadi salah satu prosedur yang digunakan untuk memperoleh SG dalam kultur in vitro pada berbagai tanaman, misalnya pada apel (Hao \& Deng, 2003), anggrek (Lopez-Puc, 2013), pisang (Edirisinghe et al., 2017), carica (Rahayu et al., 2015), kerabat kentang (Muñoz et al., 2019) dan kurma (El-Bahr et al., 2016). Penambahan bahan osmotic seperti sukrosa dan mannitol berperan sebagai penghambat pertumbuhan karena adanya tekanan osmotik. Sumber karbon ini mengurangi potensial air dan membatasi ketersediaan air bagi eksplan (review oleh da Silva and Scherwinski-Pereira, 2011). Sukrosa banyak dijumpai sebagai sumber karbohidrat dan pengatur tekanan osmotik pada studi konservasi in vitro untuk Genus Prunus (Arbeloa et al., 2017), pada kerabat anggur (Pan et al., 2014), jahe(Mengs, 2018), kurma (Mona et al., 2016), kentang 
(Nasiruddin and Islam, 2018), dan lainlain.

Karbohidrat pada kultur in vitro berperan sebagai sumber energi, pengatur tekanan osmotik dan sumber karbon. Karbohidrat dapat mempengaruhi pertumbuhan dan diferensiasi jaringan dengan mengatur ekspresi gen. Pada apel, sukrosa 3\% merupakan sumber karbon yang banyak digunakan untuk perbanyakan tunas (review oleh Dobránszki and Teixeira da Silva, 2010). Penelitian ditujukan untuk melihat pengaruh perbedaan konsentrasi media dan hormon untuk konservasi apel secara in vitro.

\section{BAHAN DAN METODE}

Penelitian dilaksanakan di laboratorium Pemuliaan Tanaman, Balai Penelitian Tanaman Jeruk dan Buah Subtropika pada bulan Agustus Desember 2018.

Eksplan apel yang digunakan sebagai materi konservasi berasal dari tunas hasil induksi meristem, yang diperbanyak dengan metode transversal thin cell layer (tTCL), dipotong dengan ketebalan $0.2 \mathrm{~mm}-1 \mathrm{~mm}$. Media perbanyakan yang digunakan berdasarkan komposisi dasar Murashige dan Skoog (MS). Tunas yang diperoleh dari perbanyakan dibesarkan dan dipelihara sampai mencapai tinggi $3-4 \mathrm{~cm}$, selanjutnya dijadikan sebagai materi konservasi. Tunas dipotong dengan ukuran 2-3 $\mathrm{mm}$ tepat dibagian nodal.

Sebanyak lima aksesi digunakan materi dalam penelitian konservasi iniyaitu aksesi batang bawah, K60, K66, K84 dan K01. Reduksi laju pertumbuhan tunas dilakukan dengan mengurangi garam media MS: full strength (FS) dan half strength (HS); penambahan sumber karbonsukrosa level $25 \quad \mathrm{~g} \quad \mathrm{~L}^{-1}$,serta penggunaan hormon benzyladenin (BA) dengan konsentrasi rendah0.1 $\mathrm{mg} \mathrm{L}^{-1}$ dan $0.2 \mathrm{mg} \mathrm{L}^{-1}$ : B1) FS + BA $0.1 \mathrm{mg} \mathrm{L}^{-1}$, B2)
FS + BA $0.2 \mathrm{mg} \mathrm{L}^{-1}$, B3) HS + BA $0.1 \mathrm{mg}$ $\left.\mathrm{L}^{-1}, \mathrm{~B} 4\right) \mathrm{HS}+\mathrm{BA} 0.2 \mathrm{mg} \mathrm{L}^{-1}$ ).

Penelitian ini menggunakan rancangan acak lengkap dengan total 4 perlakuan, masing-masing sebanyak tiga ulangan. Parameter pengamatan meliputi; jumlah tunas hidup, jumlah tunas terinduksi dan jumlah kalus terbentuk,diamati empat bulan setelah tanam.

\section{HASIL DAN PEMBAHASAN}

Konservasi merupakan upaya pelestarian keragaman sumber daya genetik (SDG) dari kepunahan, dengan tetap mempertahankan kestabilan genetik pada masing-masing individu baik secara ex vitro maupun in vitro. Salah satu metode konservasi in vitro pada SDG, melalui reduksi laju pertumbuhan dengan modifikasi media pertumbuhan. Modifikasi pertumbuhan dalam penelitian ini dilakukan dengan mengurangi garam, konsentrasi sumber karbon dan penggunaan hormone dalam konsentrasi rendah.

\section{Pengaruh media dasar dan $\mathrm{BA}$ dengan konsentrasi berbeda}

Modifikasi perlakuan yang dilakukan ditujukan untuk optimasi media konservasi dengan penambahan hormon BA dengan konsentrasi rendah serta penggunaan konsentrasi media dasar FS dan HS. Tabel 1 menunjukkan pertumbuhan eksplan dua bulan setelah kultur. K01 dan K60 memberikan respon relative baik untuk parameter jumlah eksplan hidup disbanding aksesi lainnya pada semua media yang diuji, sedangkan aksesi K66 menunjukkan performa paling rendah di semua media. Aksesi batang bawah (BB) bertahan lebih baik pada media dengan konsentrasi BA yang lebih rendah.

Induksi tunas terjadi pada seluruhaksesi yang ditanam di semua media, dengan persentase tertinggi terdapat pada aksesi K66 yang ditanam di media 
B4. Konsentrasi HS di media MS justru meningkatkan jumlah tunas yang terinduksi disbanding penggunaan media FS, sementara untuk induksi kalus masih terjadi pada semua media dan hanya aksesi K01 dan K60 yang tidak terinduksi pada media B2, B3 dan B4. Hal ini sejalan dengan hasil studi Arbeloa et al. (2017) pada tanaman buah terutama dari Genus Prunus yang mendapatkan hasil laju multiplikasi tunas lebih tinggi pada media full-strength MS dibanding media halfstrength MS dengan konsentrasi sukrosa yang sama.

Tabel 1. Pertumbuhan eskplan dengan konsentrasi media MS dan BA berbeda empat bulan setelah tanam.

\begin{tabular}{ccccc}
\hline Media & Aksesi & \% Eksplan hidup & $\begin{array}{c}\text { \% Eksplan } \\
\text { bertunas }\end{array}$ & \% Eksplan berkalus \\
\hline \multirow{4}{*}{ B1 } & BB & 77,78 & 38,89 & 33,33 \\
& K84 & 55,56 & 5,56 & 55,56 \\
& K66 & 33,33 & 22,22 & 11,11 \\
& K01 & 88,89 & 55,56 & 22,22 \\
& K60 & 77,78 & 61,11 & 0 \\
\hline \multirow{6}{*}{ B2 } & BB & 27,78 & 11,11 & 16,67 \\
& K84 & 55,56 & 33,33 & 16,67 \\
& K66 & 16,67 & 5,56 & 16,67 \\
& K01 & 77,78 & 22,22 & 33,33 \\
& K60 & 77,78 & 55,56 & 5,56 \\
\hline \multirow{5}{*}{ B3 } & BB & 66,67 & 50,00 & 0 \\
& K84 & 27,78 & 22,22 & 0 \\
& K66 & 0,00 & 0,00 & 16,67 \\
& K01 & 61,11 & 16,67 & 0 \\
\hline \multirow{6}{*}{ B4 } & K60 & 83,33 & 77,78 & 0 \\
& K8 & 33,33 & 22,22 & 0 \\
& K66 & 27,78 & 11,11 & 0 \\
& K01 & 11,11 & 11,11 & 5,56 \\
\hline
\end{tabular}

Konsentrasi sukrosa menjadi $25 \mathrm{~g} \mathrm{~L} \mathrm{~L}^{-1}$ dianggap cukup untuk mempertahankan eksplan dalam kultur in vitro terutama untuk aksesi K01 dan K66 selama empat bulan tanpa memerlukan subkultur. Namun demikian, dengan tujuan untuk konservasi jangka pendek, observasi selama empat bulan belum cukup untuk melihat daya tahan eksplan. Oleh karena itu, diperlukan uji lanjutan dengan masa observasi yang lebih panjang mendekati masa konservasi jangka pendek selama 12 bulan.ElHomosany dan Shimaa (2016)mampu mempertahankan kultur apel hingga 12 bulan dengan penambahan sorbitol. Oleh karena itu, dengan ekspektasi yang sama, modifikasi media untuk uji selanjutnya dengan perlakuan pengatur tekanan osmotik akan dilakukan. 
Tabel 2. Pengaruh aksesi terhadap pertumbuhan eksplan empat bulan setelah kultur.

\begin{tabular}{cccc}
\hline Aksesi & \% Eksplan hidup & \% eksplan bertunas & \% eksplan berkalus ${ }^{\mathrm{ns}}$ \\
\hline BB & $51.39 \mathrm{ab}$ & $30.56 \mathrm{~b}$ & 12.50 \\
K84 & $41.67 \mathrm{~b}$ & $18.06 \mathrm{bc}$ & 18.06 \\
K66 & $15.28 \mathrm{c}$ & $9.72 \mathrm{c}$ & 6.94 \\
K01 & $73.61 \mathrm{a}$ & $36.11 \mathrm{~b}$ & 19.44 \\
K60 & $76.39 \mathrm{a}$ & $62.50 \mathrm{a}$ & 1.39 \\
\hline
\end{tabular}

Keterangan: Angka diikutihurufberbeda pada kolom yang samaadalahberbedanyata pada uji DMRT taraf5\% ; ns tidaksignifikan

Analisa lanjutan pada Tabel 2 dan 3 menunjukkan adanya perbedaan yang signifikan dalam pertumbuhan eskplan sebagai pengaruh dari aksesi dan media dengan konsentrasi berbeda yang digunakan. Secara keseluruhan, aksesi K60 memberikan respon paling baik untuk pengembangan jaringan dengan arah pertunasan, sementara itu K66 menunjukkan respon paling rendah untuk semua variabel yang diamati. Media MS full strength dengan $\quad \mathrm{BA} \quad 0.1 \quad \mathrm{mg} \quad \mathrm{L}^{-1} \quad$ (B1) memberikan dukungan untuk pertumbuhan yang paling baik dengan garam yang lengkap untuk mempertahankan eksplan untuk tetap hidup. Perbedaan respon aksesi terhadap media menunjukkan kecenderungan preferensi genetik sehingga untuk aksesi lain diperlukan pengujian lain untuk optimasi media konservasi. Hal ini sesuai dengan studi Negri et al., (2000) pada konservasi apel dengan metode slow growth dengan hasil beragam antar genotipe yang diuji

Tabel 3. Pengaruh media terhadap pertumbuhan eksplan empat bulan setelah kultur.

\begin{tabular}{cccc}
\hline Media & \% Eksplan hidup & \% eksplan bertunas & \% eksplan berkalus \\
\hline B1 & $66.67 \mathrm{a}$ & $36.667 \mathrm{a}$ & $24.44 \mathrm{a}$ \\
B2 & $51.11 \mathrm{ab}$ & $25.556 \mathrm{a}$ & $17.78 \mathrm{ab}$ \\
B3 & $47.78 \mathrm{ab}$ & $33.333 \mathrm{a}$ & $3.33 \mathrm{bc}$ \\
B4 & $41.11 \mathrm{~b}$ & $30.000 \mathrm{a}$ & $1.11 \mathrm{c}$ \\
\hline
\end{tabular}

Keterangan: Angka diikuti huruf berbeda pada kolom yang sama adalah berbedanyata pada uji DMRT taraf $5 \%$

Hasil penelitian pendahuluan menunjukkan penggunaan sukrosa memberikan respon terbaik dibandingkan maltosa dan laktosa (Andrini et al., 2017, laporan tidak dipublikasikan). Selain itup eningkatan kemampuan hidup dipengaruhi oleh penambahan hormon BA konsentrasi rendah. Diduga BA memiliki kontribusi agar sel-sel tetap aktif, mengingat bahwa BA sendiri berperan penting dalam pembelahan sel dan jaringan. Namun, setiap aksesi memiliki kemampuan untuk bertahan yang berbeda sehingga konsentrasi hormon juga perlu diperhatikan. Berdasarkan kajian ini, kombinasi antara sukrosa dan BA dapat meningkatkan persentase hidup pada beberapa aksesi (K01 dan K60).
Studi konservasi apel dengan penggunaan sukrosa menunjukkan kestabilan genetic meskipun telah disimpan hingga 12 bulan (El-Homosany and Shimaa, 2016). Pengamatan lebih lanjut didiperlukan untuk melihat kestabilan genetic apel untukt ujuan konservasi secara in vitro. Hal ini dikarenakan stress terkait kegiatan konservasi dapat menyebabkan perubahan berupa metilasi DNA yang dapat menyebabkanperubahan (Hao and Deng, 2003).

Keberhasilan

konservasi dipengaruhi oleh interaksi penting antara factor fisika dan kimia dalam kultur in vitro (Rezende et al., 2018), sehingga dalam studi selanjutnya perlakuan yang dapat dicoba antara lain kombinasi suhu rendah 
dan perlakuan gelap (Benelli et al., 2012), perlakuan inhibitor etilen (Cha-um \& Kirdmanee, 2007), asam absisat (Mona et al., 2016) atau dengan mencoba media dasar lainnya seperti WPM (Alvim et al., 2020) dan zat pengatur tumbuh lainnya (Mancilla-Álvarez et al., 2019; Pan et al., 2014; Montalvo-Peniche et al., 2007; Rida et al., 2015).

\section{KESIMPULAN}

1. Media MS full strength lebihbaik dalam mempertahankan eksplan hidup dibanding half-strength selama empat bulan masa konservasi tanpa subkultur.

2. Kombinasi media MS FS dan BA 0.1 $\mathrm{mg} \mathrm{L}^{-1}$ memberikan hasil terbaik untuk konservasi apel pada aksesi K01 dan K66

\section{DAFTAR PUSTAKA}

Alvim, B. F. M., de Souza, A. V. V., LimaBrito, A., Fonseca, P. T., Soares, T. L., \& de Santana, J. R. F. (2020). In vitro conservation of Amburana cearensis (Fabaceae). Ciencia Rural, 50(7), 1-8. https://doi.org/10.1590/01038478 cr20190729

Arbeloa, A., Marín, J. A., Andreu, P., García, E., \& Lorente, P. (2017). In vitro conservation of fruit trees by slow growth storage. Acta Horticulturae, 1155, 101-106. https://doi.org/10.17660/ActaHortic. 2017.1155.13

Benelli, C., Ozudogru, E. A., Lambardi, M., \& Dradi, G. (2012). In vitro conservation of ornamental plants by slow growth storage. Acta Horticulturae, 961, 89-93. https://doi.org/10.17660/ActaHortic. 2012.961.8

Cha-um, S., \& Kirdmanee, C. (2007). Minimal growth in vitro culture for preservation of plant species. Fruit, Vegetable and Cereal Science and
Biotechnology, 1(1), 13-25.

da Silva, T.L., Scherwinski-Pereira, J. E. (2011). In vitro conservation of Piper aduncum and Piper hispidinervum under slow-growth conditions. Pesq. Agropec. Bras., 46(4), 384-389.

Dewi, I. S., Jawak, G. S., Purwoko, B. S., \& Sabda, M. (2015). Respon Pertumbuhan Kultur In Vitro Jeruk Besar (Citrus maxima (Burm.) Merr.) cv. Nambangan terhadap Osmotikum dan Retardan. Jurnal Hortikultura Indonesia, $\quad 5(1), \quad 21$. https://doi.org/10.29244/jhi.5.1.21-28 Dobránszki, J., \& Teixeira da Silva, J. A. (2010). Micropropagation of apple A review. Biotech Adv, 28(4), 462488.

https://doi.org/10.1016/j.biotechadv.2 010.02 .008

Edirisinghe, E. S. C., Denagamage, C. H., \& Samarasinghe, W. L. G. (2017). Effect of nutrient medium composotions in in vitro conservation of Musa spp. Annals of Sri Lanka Departement of Agriculture, 19(2), 60-70.

El-Bahr, M. K., Abd EL-Hamid, A., Matter, M. A., Shaltout, A., Bekheet, S. A., \& El-Ashry, A. (2016). In vitro conservation of embryogenic cultures of date palm using osmotic mediated growth agents. Journal of Genetic Engineering and Biotechnology, 14(2), 363-370. https://doi.org/10.1016/j.jgeb.2016.0 8.004

El-Homosany, A. A., \& Shimaa, M. K. (2016). In vitro Conservation of " Balady " Apple Shoot Tip Explants and Genetic Stability under Different Sugar Concentrations and Low Temperature. J.Hort. Sci. \& Ornamen.Plants, 8(3), 173-178. https://doi.org/10.5829/idosi.jhsop.20 16.173.178

Hao, Y. J., \& Deng, X. X. (2003). Genetically stable regeneration of 
apple plants from slow growth. Plant Cell, Tissue and Organ Culture, $72(3)$, 253-260 https://doi.org/10.1023/A:102238872 8497

Kḷaviņa, D., \& Kḷaviņa, D. (2018). Ex situ conservation of endangered plant species of Latvia by slow growth storage. Environmental and Experimental Biology, 16(2), 129138.

https://doi.org/10.22364/eeb.16.12

Lopez-Puc, G. (2013). An effective in vitro slow growth protocol for conservation of the orchid epidendrum chlorocorymbos Schltr. Tropical and Subtropical Agroecosystems, 16(1), 61-68.

Mancilla-Álvarez, E., Ramírez-Mosqueda, M. A., Arano-Avalos, S., NúñezPastrana, R., \& Bello-Bello, J. J. (2019). In vitro techniques to the conservation and plant regeneration of malanga (colocasia esculenta 1. schott). HortScience, 54(3), 514-518. https://doi.org/10.21273/HORTSCI1 3835-18

Mengs, B. (2018). In Vitro Conservation Of Ginger (Gingiber officinale Rosc.) By Slow Growth Culture. International Journal of Innovative Pharmaceutical Sciences and Research, 6(11), 32-38. https://doi.org/DOI:

10.21276/IJIPSR.2018.06.11.728

Mona, M. H., Rania, A. T., \& Ibrahim, I. A. (2016). In vitro conservation of date palm embryos under slowgrowth conditions with osmotic agent and abscisic acid. International Journal of PharmTech Research, 9(10), 173-183.

Montalvo-Peniche, M. D. C., IglesiasAndreu, L. G., Mijangos-Cortés, J. O., Nahuat-Dzib, S. L., Barahona-Pérez, F., Canto-Flick, A., \& SantanaBuzzy, N. (2007). In vitro germplasm conservation of Habanero pepper
(Capsicum chinense Jacq.).

HortScience, 42(5), 1247-1252.

Muñoz, M., Díaz, O., Reinún, W., Winkler, A., \& Quevedo, R. (2019). Slow growth in vitro culture for conservation of Chilotanum potato germplasm. Chilean J. of Agricultural Research, 79(1), 26-35. https://doi.org/10.4067/s071858392019000100026

Nasiruddin, M., \& Islam, A. K. M. R. (2018). in Vitro Slow-Growth Conservation for Two Genotypes of Solanum Tuberosum L. Bangladesh J. Bot., 47(3), 369-380.

Negri, V., Tosti, N., \& Standardi, A. (2000). Slow growth storage of single node shoots of apple genotypes . Plant Cell , Slow-growth storage of single node shoots of apple genotypes. Plant Cell, Tissue and Organ Culture, (62), 159-162.

Oseni, O. M., Pande, V., \& Nailwal, T. K. (2018). A Review on Plant Tissue Culture, A Technique for Propagation and Conservation of Endangered Plant Species. International Journal of Current Microbiology and Applied Sciences, 7(07), 3778-3786. https://doi.org/10.20546/ijcmas.2018. 707.438

Pan, X. J., Zhang, W. E., \& Li, X. (2014). In vitro conservation of native Chinese wild grape (Vitis heyneana Roem. \& Schult) by slow growth culture. Vitis - Journal of Grapevine Research, 53(4), 207-214.

Rahayu, E. S., Habibah, N. A., \& Herlina, L. (2015). Development of In Vitro Conservation Medium of Carica pubescens Lenne \& K. Koch through Nutrients Concentration Reduction and Osmoregulator Addition. Biosaintifika: Journal of Biology \& Biology Education, 7(1), 29-36. https://doi.org/10.15294/biosaintifika .$v 7 \mathrm{i} 1.3541$ 
Rezende, R. A. L. S., Rodrigues, F. A., Rezende, R. M., Soares, J. D. R., Pasqual, M., \& de Assis, F. A. (2018). In vitro conservation of Cape gooseberry through slow-growth nodal segment cultures. Pesquisa Agropecuaria Brasileira, 53(5), 651655. https://doi.org/10.1590/S0100204X2018000500015

Rida, A. S., Qudah, T., \& Al-Abdallat, A. (2015). In Vitro Conservation and Cryopreservation of Medicinal and Aromatic Plants: A Review, 11(1), 147-167.

https://doi.org/10.12816/0030081

Sedlak, J., Zidova, P., \& Paprstein, F. (2019). Slow growth in vitro conservation of fruit crops. Acta Hort, 1234 , 119-124. https://doi.org/10.17660/ActaHortic. 2019.1234.15 